\title{
MUC2 Gene
}

National Cancer Institute

\section{Source}

National Cancer Institute. MUC2 Gene. NCI Thesaurus. Code C115185.

This gene plays a role in the lubrication of mucosal surfaces. 